\title{
The GSK-3/ $\beta$-catenin-signalling axis in smooth muscle and its relationship with remodelling
}

\author{
Reinoud Gosens • Herman Meurs • Martina Schmidt
}

Received: 11 December 2007 / Accepted: 30 January 2008

(C) The Author(s) 2008

\begin{abstract}
Catenin is a plasma membrane-associated protein that plays a dual role in cellular signalling by stabilizing cadherin mediated cell-cell contact and by regulating TCF-/LEF-mediated gene transcription. Traditionally, the role of $\beta$-catenin in health and disease has mainly been studied in the context of development and uncontrolled cell growth in diseases such as cancer. Recent findings indicate, however, that $\beta$-catenin also plays a significant role in fibro-proliferative diseases of several organ systems and that $\beta$-catenin regulates mitogenic responses of smooth muscle cells. As several diseases of the internal organs are characterized by structural and phenotypic abnormalities of smooth muscle, including increased fibro-proliferative responses, these findings implicate that $\beta$-catenin could play a broad pathophysiological role. This article will review this potential novel role for $\beta$ catenin and associated intracellular signalling in smooth muscle and discuss the hypothesis that it plays a central role in smooth muscle remodelling.
\end{abstract}

Keywords Smooth muscle $\cdot \beta$-catenin $\cdot$ Cadherin

\section{Introduction}

Smooth muscle cells are key players in various internal organs, including the vasculature, airways, urogenital, and

The authors wish to dedicate this manuscript to Prof. Dr Johan Zaagsma.

R. Gosens $(\triangle) \cdot$ H. Meurs $\cdot$ M. Schmidt

Department of Molecular Pharmacology,

University of Groningen,

Antonius Deusinglaan 1,

9713 AV Groningen, The Netherlands

e-mail: r.gosens@rug.nl gastrointestinal tracts by regulation of tone and motility of these organs, which is essential to their normal physiological function. However, smooth muscle cells may also play a detrimental role in these organs under pathophysiological conditions, contributing for instance to neointima formation in the vasculature during atherosclerosis and to airflow limitation in the airways during asthma. Remodelling of the smooth muscle layer underpins part of the abnormal smooth muscle behaviour in some of these disorders. In the vasculature for instance, smooth muscle cell proliferation contributes to neointima formation during atherosclerosis, restenosis after angioplasty and stent placement, and vascular rejection (George and Dwivedi 2004). Moreover, remodelling of the airway smooth muscle is a pathological feature observed in asthma and in chronic obstructive pulmonary disease (COPD). Thus, the airway smooth muscle layer is thickened, in asthma, caused by hyperplasia and hypertrophy (Benayoun et al. 2003; Ebina et al. 1993; Woodruff et al. 2004). In COPD, thickening of the airway smooth muscle bundle is not as pronounced as it is in asthma; but several reports indicate that airway smooth muscle thickening occurs in COPD patients (Hogg et al. 2004; Jeffery 2001; Jeffery 2004; Kuwano et al. 1993; Lambert et al. 1993). Remodelling of the pulmonary vasculature in asthma and COPD has also been reported (Postma and Timens 2006). A comprehensive overview of the nature of smooth muscle remodelling in disease is beyond the scope of this review; nonetheless from the data summarized above, it is evident that structural and phenotypic abnormalities of smooth muscle has impact on disease progression in several pathological conditions. Though numerous cytokines and growth factors have been demonstrated to regulate these abnormalities, the precise intracellular mechanisms that regulate remodelling of smooth muscle are only partially understood. Recently, it 
was demonstrated that the transcriptional co-activator $\beta$ catenin may act as an important signal for smooth muscle cell proliferation (George and Beeching 2006; George and Dwivedi 2004). This article will review this potential novel role for $\beta$-catenin and associated intracellular signalling in smooth muscle and discuss the hypothesis that this pathway plays a central role in smooth muscle remodelling.

\section{The GSK-3-/ $\beta$-catenin signalling axis}

$\beta$-Catenin is a plasma membrane-associated protein that plays a dual role in cellular signalling. $\beta$-Catenin is part of a cadherin/catenin complex at the adherens junction that stabilizes cell-cell contact. In addition, it serves a role in activating gene transcription as translocation of $\beta$-catenin to the nucleus, is a signal for the activation of T-cell factor (TCF)-/lymphoid-enhancer factor (LEF) transcription factors (Clevers 2006). $\beta$-catenin localization at the plasma membrane is controlled by a cytosolic multiprotein complex consisting of the proteins axin, adenomatosis polyposis coli (APC) and glycogen synthase kinase-3 (GSK-3; Clevers 2006; Doble and Woodgett 2003). This complex regulates $\beta$-catenin phosphorylation when released into the cytosol, which is a signal for ubiquitination and lysosomal degradation of $\beta$-catenin (Clevers 2006; Doble and Woodgett 2003). This mechanism is crucial for maintenance of mitogenic quiescence: when targeted to the nucleus, $\beta$ catenin promotes transcription of TCF-/LEF-dependent genes, which include cell cycle regulatory proteins (e.g., cyclin D1), growth factors (e.g., VEGF), matrix proteins (e.g. fibronectin, versican), proteases (e.g. metalloproteinase (MMP)-2, -7, -9) and pro-inflammatory enzymes and mediators (e.g., cyclo-oxygenase (COX)-2 and interleukin (IL)-8) (Brabletz et al. 1999; De Langhe et al. 2005; Gradl et al. 1999; Howe et al. 1999; Masckauchan et al. 2005; Rahmani et al. 2005; Tetsu and McCormick 1999; Wu et al. 2007; Zhang et al. 2001). A complete list of TCF-/LEFdependent genes that are regulated by $\beta$-catenin can be found at http://www.stanford.edu/ rnusse/wntwindow.html.

In addition, GSK-3, which is constitutively active, has direct effects, independent of $\beta$-catenin. GSK-3 directly phosphorylates cyclin D1 and targets it for proteolytic breakdown (Diehl et al. 1998); GSK-3 also exerts inhibitory effects on the transcription factors c-Myc and c-Jun, which implies that GSK-3 suppresses cell proliferation (Boyle et al. 1991; Pulverer et al. 1994). Furthermore, active GSK-3 inhibits myocardin (Badorff et al. 2005), a transcriptional coactivator that is critical for contractile and contraction regulatory protein accumulation in smooth muscle (Wang et al. 2003). This implies a repressive role for GSK-3 in the regulation of contractile protein expression in smooth muscle cells and, as such, in smooth muscle maturation.
The aforementioned observations suggest that aberrant activation of the $\beta$-catenin-/GSK-3-signalling axis, for instance by regulated inactivation of GSK-3 through Ser9/ 21 phosphorylation, triggers pathological responses. Such an aberrant activation of mesenchymal $\beta$-catenin/GSK-3 signalling has recently been shown to play a central initiating role in fibro-proliferative diseases of the kidney and vasculature (Iwano and Neilson 2004; Wang et al. 2002). Furthermore, in the lung, aberrant $\beta$-catenin/GSK-3 signalling was recently implicated in idiopathic pulmonary fibrosis (IPF) (Chilosi et al. 2003). Collectively, this indicates an important role for $\beta$-catenin signalling in several fibro-proliferative disorders.

Key to understanding how this pathway is regulated during health and disease is to understand how GSK-3 phosphorylation is regulated, as this appears to be a critical step in directing $\beta$-catenin to the nucleus. GSK-3 can be serine phosphorylated (Ser 9 for GSK-3 $\beta /$ Ser 21 for GSK$3 \alpha$ ) by several protein kinases, including integrin-linked kinase (ILK), protein kinase C (PKC) and protein kinase B (PKB/Akt; Cross et al. 1995; Delcommenne et al. 1998; Goode et al. 1992). These protein kinases are activated by a variety of receptor classes, including cytokine receptors, receptor tyrosine kinases (RTKs), integrins and G proteincoupled receptors (GPCRs), suggesting that GSK-3 may act as a point of convergence for several signalling cascades (Doble and Woodgett 2003; Frame and Cohen 2001; Grimes and Jope 2001). This suggests a central role for GSK-3 in regulating tissue remodelling in response to a variety of inflammatory mediators, growth factors, contractile agonists and matrix proteins, which will be discussed further in the sections below. Interestingly, it also suggests that GSK-3/ $\beta$-catenin signalling may contribute to the progressive nature of tissue remodelling as the growth factors, cytokines and matrix proteins produced as a result of aberrant GSK-3/ $\beta$-catenin regulation may immediately feed forward into the system by suppressing GSK-3 activity further. This hypothesis is summarized in Fig. 1.

\section{The $\beta$-catenin/cadherin complex}

Subcellular $\beta$-catenin localization is, to a large extent, also actively regulated by cadherins. Cadherins are transmembrane glycoproteins that support homophilic cell-cell contact and maintain tissue cohesion (Halbleib and Nelson 2006). The cadherin family of proteins contains several subclasses, of which the classical cadherins have been most extensively studied. Classical cadherins bind to $\beta$-catenin, which stabilizes cell-cell contact by providing a physical link between the cadherin/catenin complex and the actin cytoskeleton (Halbleib and Nelson 2006). Thus, classical cadherins play an important role in adherens junction 


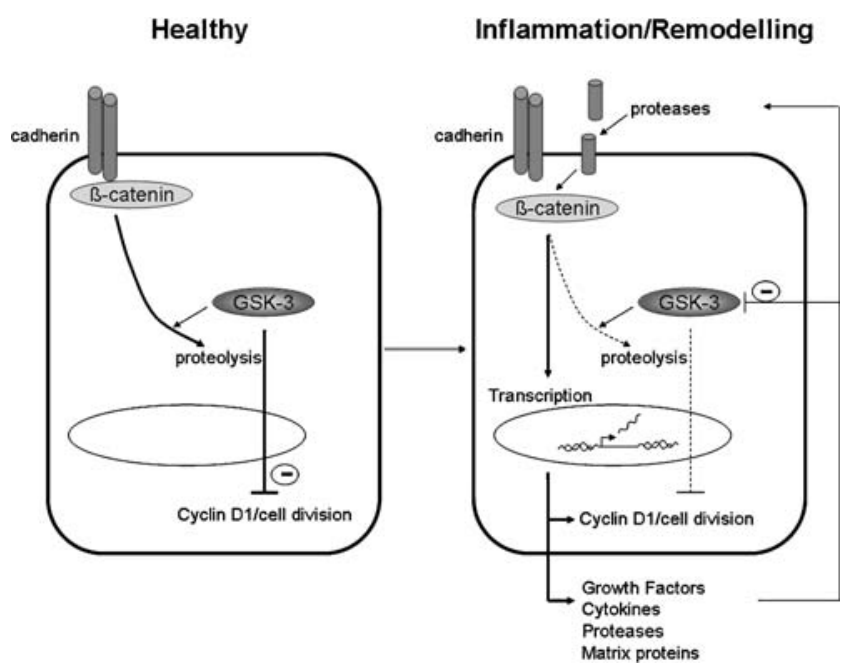

Fig. 1 Hypothetical role of the GSK-3/ $\beta$-catenin signalling axis in smooth muscle remodelling. $\beta$-Catenin is a membrane-associated protein that is bound to cadherins and stabilizes cell-cell contact in quiescent cells. Under normal circumstances, this complex is stably expressed at the plasma membrane in smooth muscle cells (left panel). $\beta$-Catenin that enters the cytoplasm is immediately broken down by GSK-3-dependent phosphorylation, resulting in its ubiquitination. GSK-3 also suppresses cell growth directly, by promoting the degradation of cyclin D1. During inflammation and remodelling, however, growth factors, cytokines, matrix proteins and proteases are released that could inhibit GSK-3 and disassemble cadherin-catenin complexes by promoting cadherin degradation (right panel). This results in $\beta$-catenin nuclear translocation, which promotes the transcription of TCF-/LEF-dependent genes, resulting in cell growth and the release of growth factors, cytokines, matrix proteins and proteases. The released substances could immediately feed forward into the system, possibly creating a vicious circle that may underpin aberrant repair and progressive smooth muscle remodeling

formation and have been widely studied for their role in regulating epithelial and endothelial barrier function. Components of the cadherin/ $\beta$-catenin complex are, however, also expressed in mesenchymal cell types. The cadherin subtypes expressed are different from epithelial cells, with reported expression of P-, R- and N-cadherin in fibroblasts (El Sayegh et al. 2007) and T-, R- and Ncadherin in vascular smooth muscle cells (George and Beeching 2006; George and Dwivedi 2004). Our own studies further indicate that airway smooth muscle cells express R-cadherin protein, and have mRNA for Pcadherin, though E-and VE-cadherin are absent (R. Gosens and I.S.T. Bos; unpublished observations). The precise role of the cadherin subtypes in these cells is incompletely understood, but initial studies indicate that disassembly of the $\mathrm{R}$ - or $\mathrm{N}$-cadherin/ $\beta$-catenin complex in vascular smooth muscle cells promotes cell proliferation, as detailed below (Slater et al. 2004; Uglow et al. 2003). This suggests that inflammatory insults that modulate cell-cell contacts in the vessel wall may use this mechanism to regulate wound repair and tissue remodelling.

\section{$\beta$-catenin signalling in smooth muscle remodelling}

Based on the data described above, there is a strong rationale for a role for $\beta$-catenin and associated intracellular signalling in regulating responses that drive tissue remodelling. So what is the available evidence that this pathway regulates smooth muscle function?

Cell proliferation Compelling evidence exists for a role of the GSK-3-/ $\beta$-catenin signalling axis in proliferation and apoptosis of smooth muscle cells. Pharmacological inhibition of GSK-3 increases cyclin D1 abundance in human airway smooth muscle cells, and potentiates growth-factorinduced retinoblastoma $(\mathrm{Rb})$ protein phosphorylation and cell cycle progression, as assessed by flow cytometric analysis (Gosens et al. 2007). This indicates a repressive role for GSK-3 in airway smooth muscle cell proliferation, as would be expected from the data described in earlier sections. Interestingly, the repressive role of GSK-3 could be reversed by platelet-derived growth factor (PDGF) and foetal bovine serum that both induced sustained GSK-3 phosphorylation (Gosens et al. 2007). Similarly, baseline GSK-3 phosphorylation was highest in cells with a proliferative phenotype compared to quiescent cultures. A similar role for GSK-3 exists in vascular smooth muscle. For example, transfection of rat aortic smooth muscle cells with GSK-3 $\beta$ induces apoptosis, which can be reversed by co-transfection of these cells with a nondegradable $\beta$ catenin mutant (Wang et al. 2002). Furthermore, balloon injury in the rat carotid artery induced GSK-3 phosphorylation within the vascular smooth muscle bundle (Hall et al. 2001), and gene transfer of a dominant negative GSK-3 (S9A) inhibits balloon injury-induced neointima formation in the rat carotid artery, reduced smooth muscle cell proliferation and augmented apoptosis (Park et al. 2003). Increased phosphorylation and inhibition of GSK-3 by IGF1 also protects human intestinal smooth muscle cells from apoptosis (Kuemmerle 2005). Collectively, these data indicate that GSK-3 suppresses smooth muscle cell proliferation and induces apoptosis, which can be actively reversed by growth factor stimulation. This suggests a central role for GSK-3 in regulating smooth muscle remodelling in response to a variety of stimuli. This hypothesis is summarized in Fig. 1.

$\beta$-Catenin likely plays a central role in the observed effects of GSK-3. First, $\beta$-catenin expression can be induced by growth factor treatment, presumably as a result of sustained GSK-3 inhibition, which results in reduced intracellular breakdown of the protein. Thus, proliferating human airway smooth muscle cells express increased levels of $\beta$-catenin protein compared to quiescent cultures, and prolonged treatment of airway myocytes with foetal bovine serum increases $\beta$-catenin protein expression (Nunes et al., 
unpublished observations). Moreover, IGF-1 treatment of human intestinal smooth muscle cells prevents $\beta$-catenin phosphorylation by GSK-3, resulting in reduced intracellular $\beta$-catenin breakdown (Kuemmerle 2005). Moreover, overexpression of a $\beta$-catenin mutant that cannot be degraded by GSK-3 prevents GSK-3 induced apoptosis, whereas overexpression of wild-type $\beta$-catenin does not have this anti-apoptotic effect (Wang et al. 2002). Second, the subcellular localization of $\beta$-catenin is also regulated by growth factor treatment. Thus, foetal bovine serum treatment induces accumulation of $\beta$-catenin protein in the nuclear fraction, which is responsible for its effects on $\beta$ catenin-dependent gene transcription in smooth muscle of the human saphenous vein (Uglow et al. 2003). These data collectively indicate that GSK-3 promotes intracellular $\beta$ catenin breakdown. This inhibitory role is reversed by growth factors, resulting in intracellular $\beta$-catenin accumulation and nuclear translocation.

The crucial role for GSK-3 inhibition and $\beta$-catenin nuclear translocation in smooth muscle cell proliferation is evidenced based on the fact that overexpression of a dominant negative TCF-4, which mediates the nuclear effects of $\beta$-catenin on gene transcription in human aortic and saphenous vein smooth muscle, inhibited the effects of PDGF and foetal bovine serum on smooth muscle proliferation (Quasnichka et al. 2006). Furthermore, overexpression of inhibitor of $\beta$-catenin and TCF-4 (ICAT), a protein that interferes with the interaction of $\beta$-catenin and TCF, reduced smooth muscle proliferation (Quasnichka et al. 2006). Collectively, these results points to a crucial role for $\beta$-catenin in mediating the effects of growth factors on smooth muscle cell growth, likely through regulated inactivation of GSK-3 by phosphorylation. Therefore, $\beta$ catenin could play a role in smooth muscle thickening, which is further indicated by observations that $\beta$-catenin expression and nuclear localization are increased after balloon injury of the rat carotid artery (Slater et al. 2004; Wang et al. 2002) and by observations that overexpression of a dominant negative TCF-4 inhibits smooth muscle cell proliferation induced by foetal bovine serum in the human saphenous vein in situ (Quasnichka et al. 2006).

GSK-3 is also involved in the cooperative induction of smooth muscle cell proliferation by GPCR agonists RTKs. GPCR agonists, including those that lack effect on smooth muscle cell proliferation by themselves, often augment the proliferative effects of RTK ligands in a synergistic fashion (Deshpande and Penn 2006). For example, the G proteincoupled muscarinic receptor agonist methacholine, which does not induce airway smooth muscle proliferation by itself, potentiates PDGF-induced cell cycle progression and $\mathrm{Rb}$ phosphorylation (Gosens et al. 2007). Notably, the effects of methacholine and PDGF on GSK-3 phosphorylation can explain these differential effects on cell proliferation. Thus,
GSK-3 phosphorylation induced by PDGF sustained over time and resulted in cell cycle progression, whereas GSK-3 phosphorylation induced by muscarinic receptor stimulation was transient and not sufficient for cell proliferation (Gosens et al. 2007). The combination of methacholine with PDGF, however, was associated with synergistic effects on GSK-3 phosphorylation that sustained over several hours (Gosens et al. 2007). Of note, cross-talk of GPCR and RTK ligands likely requires multiple signalling arms, which include GSK-3 and PI3K, the latter also being cooperatively regulated by $\mathrm{G}_{\mathrm{q}}$-derived $\beta \gamma$ subunits and RTK stimulation (Billington et al. 2005; Kong et al. 2006). Therefore, PI3K and GSK-3 may act as points of convergence for GPCR and RTK signalling and explain, in part, the receptor cross-talk between these receptor systems that drives synergistic cell responses.

In addition to GSK-3, cadherins also play a crucial role in repressing smooth muscle cell proliferation. Growth factors reduce $\mathrm{N}$-cadherin expression in cultured vascular smooth muscle cells derived from the human saphenous vein, which is dependent on matrix metalloproteinase (MMP) activity, suggesting a mechanism in which cleavage of $\mathrm{N}$-cadherin promotes $\beta$-catenin release from the plasma membrane, resulting in nuclear translocation and cell proliferation (Uglow et al. 2003). Moreover, balloon injury reduces $\mathrm{R}$-cadherin expression in the rat carotid artery, which is associated with increased $\beta$-catenin and cyclin D1 abundance within the smooth muscle layer (Slater et al. 2004). These studies indicate that dynamic regulation of cadherin expression regulates smooth muscle cell proliferation in the systemic vasculature. Collectively, the aforementioned data indicate that $\beta$-catenin, GSK-3 and cadherins regulate mitogenic behaviour of smooth muscle derived from several organ systems. Its role in systemic vascular smooth muscle remodelling in particular has been focus of study. The potential role of this pathway in other diseases involving smooth muscle remodelling, e.g., airway and pulmonary vascular smooth muscle remodelling in asthma and COPD, still needs to be elucidated.

Hypertrophy GSK-3 plays an important role in regulating myocyte hypertrophy (Kerkela et al. 2007). This may not be primarily dependent on $\beta$-catenin, but rather on the direct effects of GSK-3 on protein translation and gene transcription of contractile proteins. Phosphorylation of GSK-3, for instance by hypertrophic growth factors such as IGF-1 or insulin, removes the inhibitory constraint on eukaryotic initiation factor (eIF)2B, which stimulates protein translation that is necessary for cellular hypertrophy in skeletal muscle (Jefferson et al. 1999; Rommel et al. 2001). Recent studies in vascular and airway smooth muscle indicate that this mechanism is also operative in smooth muscle cells. First, mechanisms that direct protein 
translation, including PKB (which is upstream of GSK-3), and its downstream effectors mammalian target of rapamycin (mTOR), 4EBP-1 and p70S6K are known to play a crucial role in regulating airway smooth muscle cell hypertrophy and contractile protein accumulation (Goldsmith et al. 2006; Gosens et al. 2003; Halayko et al. 2004; Schaafsma et al. 2007). Second, induction of total protein expression (suggestive of hypertrophy) by endothelin-1 in rat aortic smooth muscle was associated with phosphorylation and inactivation of GSK-3 (Taurin et al. 2007). Third, GSK-3 phosphorylation removes the inhibitory constraint on myocardin (Badorff et al. 2005), a transcription factor that is necessary for smooth muscle-specific protein expression (Wang et al. 2003), and finally, initial studies in airway smooth muscle cells indicate that lithium, which inhibits GSK-3 activity or GSK-3 siRNA both increase cell size and contractile protein expression (Deng et al. 2007). Collectively, these results indicate that GSK-3 inhibition likely plays an important role in contractile protein expression and cellular hypertrophy in smooth muscle, by regulating protein translation and by regulating myocardin-dependent smooth muscle-specific gene transcription.

Pro-fibrotic and secretory function Although $\beta$-catenin and TCF-dependent gene transcription has been associated with the production of pro-inflammatory mediators, growth factors and cytokines (e.g., COX-2, VEGF, IL-8; Howe et al. 1999; Masckauchan et al. 2005; Zhang et al. 2001), the importance of this mechanism for cytokine production by smooth muscle is unknown and warrants future investigation. However, the production of the matrix component versican has been linked to a GSK3-/ $\beta$-catenin-/TCFdependent mechanism in rat aortic smooth muscle cells (Rahmani et al. 2005), suggesting that this pathway may contribute to extracellular matrix production. Whether the capacity of smooth muscle cells to synthesize other relevant molecules (e.g., matrix protein production, cytokine production) is also $\beta$-catenin-dependent is unknown at this point, however, future studies in this area are needed.

\section{Conclusions and future perspectives}

The $\beta$-catenin signalling pathway has traditionally been associated with development and with diseases such as cancer (Barker and Clevers 2006). However, recent research indicates that this pathway is also activated during fibrosis and tissue remodelling in several organ systems (Chilosi et al. 2003; Douglas et al. 2006). The contention that the role of $\beta$-catenin exceeds development is reinforced by studies that demonstrate that this pathway is regulated in response to mediators of inflammation, including MMPs, growth factors and cytokines (George and Dwivedi 2004). Indeed, the output of $\beta$-catenin-/TCF-/LEF-dependent gene transcription (cell cycle regulatory proteins, growth factors, proteases, cytokines, matrix proteins) suggests that this pathway may actively regulate essential aspects of inflammation and remodelling. Convincing in vitro evidence now indicates a role for this pathway in myocyte function, including cell proliferation (Gosens et al. 2007; Slater et al. 2004; Uglow et al. 2003). Therefore, a thus far unappreciated role for $\beta$-catenin in pathological remodelling of smooth muscle can be hypothesized.

Several open questions exist, however, which preclude stronger conclusions at this point. In particular, the role of $\beta$-catenin in smooth muscle secretory and pro-fibrotic function is not well studied, even though a clear rationale for such a role exists. Most importantly, the functional contribution of this pathway to smooth muscle remodelling and inflammation needs to be determined using appropriate animal models and clinical samples. Current evidence available in the literature provides a strong and attractive rationale for such studies, and suggests that inhibition of $\beta$ catenin-/TCF-/LEF-dependent gene transcription using small molecule inhibitors holds promise as a new pharmacological principle (Barker and Clevers 2006).

Acknowledgements Reinoud Gosens is the recipient of a Veni grant (916.86.036) from the Netherlands Organisation for Scientific Research (NWO). Martina Schmidt is the recipient of a Rosalind Franklin Fellowship from the University of Groningen.

Open Access This article is distributed under the terms of the Creative Commons Attribution Noncommercial License which permits any noncommercial use, distribution, and reproduction in any medium, provided the original author(s) and source are credited.

\section{References}

Badorff C, Seeger FH, Zeiher AM, Dimmeler S (2005) Glycogen synthase kinase 3beta inhibits myocardin-dependent transcription and hypertrophy induction through site-specific phosphorylation. Circ Res 97:645-654

Barker N, Clevers H (2006) Mining the Wnt pathway for cancer therapeutics. Nat Rev Drug Discov 5:997-1014

Benayoun L, Druilhe A, Dombret MC, Aubier M, Pretolani M (2003) Airway structural alterations selectively associated with severe asthma. Am J Respir Crit Care Med 167:1360-1368

Billington CK, Kong KC, Bhattacharyya R, Wedegaertner PB, Panettieri RA Jr., Chan TO, Penn RB (2005) Cooperative regulation of p70S6 kinase by receptor tyrosine kinases and $G$ protein-coupled receptors augments airway smooth muscle growth. Biochemistry 44:14595-14605

Boyle WJ, Smeal T, Defize LH, Angel P, Woodgett JR, Karin M, Hunter T (1991) Activation of protein kinase C decreases phosphorylation of c-Jun at sites that negatively regulate its DNA-binding activity. Cell 64:573-584 
Brabletz T, Jung A, Dag S, Hlubek F, Kirchner T (1999) beta-catenin regulates the expression of the matrix metalloproteinase-7 in human colorectal cancer. Am J Pathol 155:1033-1038

Chilosi M, Poletti V, Zamo A, Lestani M, Montagna L, Piccoli P, Pedron S, Bertaso M, Scarpa A, Murer B, Cancellieri A, Maestro R, Semenzato G, Doglioni C (2003) Aberrant Wnt/beta-catenin pathway activation in idiopathic pulmonary fibrosis. Am J Pathol $162: 1495-1502$

Clevers H (2006) Wnt/beta-catenin signaling in development and disease. Cell 127:469-480

Cross DA, Alessi DR, Cohen P, Andjelkovich M, Hemmings BA (1995) Inhibition of glycogen synthase kinase-3 by insulin mediated by protein kinase B. Nature 378:785-789

De Langhe SP, Sala FG, Del Moral PM, Fairbanks TJ, Yamada KM, Warburton D, Burns RC, Bellusci S (2005) Dickkopf-1 (DKK1) reveals that fibronectin is a major target of Wnt signaling in branching morphogenesis of the mouse embryonic lung. Dev Biol 277:316-331

Delcommenne M, Tan C, Gray V, Rue L, Woodgett J, Dedhar S (1998) Phosphoinositide-3-OH kinase-dependent regulation of glycogen synthase kinase 3 and protein kinase B/AKT by the integrin-linked kinase. Proc Natl Acad Sci U S A 95:11211-11216

Deng H, Dokshin GA, Lei J, Goldsmith AM, Bitar KN, Fingar DC, Hershenson MB, Bentley JK (2008) Inhibition of glycogen synthase kinase-3beta is sufficient for airway smooth muscle hypertrophy. J Biol Chem (in press) DOI 10.1074/jbc. M800624200

Deshpande DA, Penn RB (2006) Targeting G protein-coupled receptor signaling in asthma. Cell Signal 18:2105-2120

Diehl JA, Cheng M, Roussel MF, Sherr CJ (1998) Glycogen synthase kinase-3beta regulates cyclin D1 proteolysis and subcellular localization. Genes Dev 12:3499-3511

Doble BW, Woodgett JR (2003) GSK-3: tricks of the trade for a multitasking kinase. J Cell Sci 116:1175-1186

Douglas IS, Diaz DV, Winn RA, Voelkel NF (2006) Beta-catenin in the fibroproliferative response to acute lung injury. Am J Respir Cell Mol Biol 34:274-285

Ebina M, Takahashi T, Chiba T, Motomiya M (1993) Cellular hypertrophy and hyperplasia of airway smooth muscles underlying bronchial asthma. A 3-D morphometric study. Am Rev Respir Dis 148:720-726

El Sayegh TY, Kapus A, McCulloch CA (2007) Beyond the epithelium: cadherin function in fibrous connective tissues. FEBS Lett 581:167-174

Frame S, Cohen P (2001) GSK3 takes centre stage more than 20 years after its discovery. Biochem J 359:1-16

George SJ, Dwivedi A (2004) MMPs, cadherins, and cell proliferation. Trends Cardiovasc Med 14:100-105

George SJ, Beeching CA (2006) Cadherin:catenin complex: a novel regulator of vascular smooth muscle cell behaviour. Atherosclerosis $188: 1-11$

Goldsmith AM, Bentley JK, Zhou L, Jia Y, Bitar KN, Fingar DC, Hershenson MB (2006) Transforming growth factor-beta induces airway smooth muscle hypertrophy. Am J Respir Cell Mol Biol 34:247-254

Goode N, Hughes K, Woodgett JR, Parker PJ (1992) Differential regulation of glycogen synthase kinase- 3 beta by protein kinase C isotypes. J Biol Chem 267:16878-16882

Gosens R, Nelemans SA, Hiemstra M, Grootte Bromhaar MM, Meurs H, Zaagsma J (2003) Insulin induces a hypercontractile airway smooth muscle phenotype. Eur J Pharmacol 481:125-131

Gosens R, Dueck G, Rector E, Nunes RO, Gerthoffer WT, Unruh H, Zaagsma J, Meurs H, Halayko AJ (2007) Cooperative regulation of GSK3 by muscarinic and PDGF receptors is associated with airway myocyte proliferation. Am J Physiol Lung Cell Mol Physiol 293:L1348-L1358
Gradl D, Kuhl M, Wedlich D (1999) The Wnt/Wg signal transducer beta-catenin controls fibronectin expression. Mol Cell Biol 19:5576-5587

Grimes CA, Jope RS (2001) The multifaceted roles of glycogen synthase kinase 3beta in cellular signaling. Prog Neurobiol 65:391-426

Halayko AJ, Kartha S, Stelmack GL, McConville J, Tam J, CamorettiMercado B, Forsythe SM, Hershenson MB, Solway J (2004) Phophatidylinositol-3 kinase/mammalian target of rapamycin/ p70S6K regulates contractile protein accumulation in airway myocyte differentiation. Am J Respir Cell Mol Biol 31:266-275

Halbleib JM, Nelson WJ (2006) Cadherins in development: cell adhesion, sorting, and tissue morphogenesis. Genes Dev 20:3199-3214

Hall JL, Chatham JC, Eldar-Finkelman H, Gibbons GH (2001) Upregulation of glucose metabolism during intimal lesion formation is coupled to the inhibition of vascular smooth muscle cell apoptosis. Role of GSK3beta. Diabetes 50:1171-1179

Hogg JC, Chu F, Utokaparch S, Woods R, Elliott WM, Buzatu L, Cherniack RM, Rogers RM, Sciurba FC, Coxson HO, Pare PD (2004) The nature of small-airway obstruction in chronic obstructive pulmonary disease. N Engl J Med 350:2645-2653

Howe LR, Subbaramaiah K, Chung WJ, Dannenberg AJ, Brown AM (1999) Transcriptional activation of cyclooxygenase-2 in Wnt-1transformed mouse mammary epithelial cells. Cancer Res 59:1572-1577

Iwano M, Neilson EG (2004) Mechanisms of tubulointerstitial fibrosis. Curr Opin Nephrol Hypertens 13:279-284

Jefferson LS, Fabian JR, Kimball SR (1999) Glycogen synthase kinase- 3 is the predominant insulin-regulated eukaryotic initiation factor 2B kinase in skeletal muscle. Int J Biochem Cell Biol 31:191-200

Jeffery PK (2001) Remodeling in asthma and chronic obstructive lung disease. Am J Respir Crit Care Med 164:S28-S38

Jeffery PK (2004) Remodeling and inflammation of bronchi in asthma and chronic obstructive pulmonary disease. Proc Am Thorac Soc $1: 176-183$

Kerkela R, Woulfe K, Force T (2007) Glycogen synthase kinase-3beta - actively inhibiting hypertrophy. Trends Cardiovasc Med $17: 91-96$

Kong KC, Billington CK, Gandhi U, Panettieri RA Jr., Penn RB (2006) Cooperative mitogenic signaling by $G$ protein-coupled receptors and growth factors is dependent on $\mathrm{G}(\mathrm{q} / 11)$. FASEB $\mathrm{J}$ 20:1558-1560

Kuemmerle JF (2005) Endogenous IGF-I protects human intestinal smooth muscle cells from apoptosis by regulation of GSK-3 beta activity. Am J Physiol Gastrointest Liver Physiol 288:G101-G110

Kuwano K, Bosken CH, Pare PD, Bai TR, Wiggs BR, Hogg JC (1993) Small airways dimensions in asthma and in chronic obstructive pulmonary disease. Am Rev Respir Dis 148:1220-1225

Lambert RK, Wiggs BR, Kuwano K, Hogg JC, Pare PD (1993) Functional significance of increased airway smooth muscle in asthma and COPD. J Appl Physiol 74:2771-2781

Masckauchan TN, Shawber CJ, Funahashi Y, Li CM, Kitajewski J (2005) Wnt/beta-catenin signaling induces proliferation, survival and interleukin-8 in human endothelial cells. Angiogenesis 8:43-51

Park KW, Yang HM, Youn SW, Yang HJ, Chae IH, Oh BH, Lee MM, Park YB, Choi YS, Kim HS, Walsh K (2003) Constitutively active glycogen synthase kinase-3beta gene transfer sustains apoptosis, inhibits proliferation of vascular smooth muscle cells, and reduces neointima formation after balloon injury in rats. Arterioscler Thromb Vasc Biol 23:1364-1369

Postma DS, Timens W (2006) Remodeling in asthma and chronic obstructive pulmonary disease. Proc Am Thorac Soc 3:434-439

Pulverer BJ, Fisher C, Vousden K, Littlewood T, Evan G, Woodgett JR (1994) Site-specific modulation of c-Myc cotransformation by residues phosphorylated in vivo. Oncogene 9:59-70 
Quasnichka H, Slater SC, Beeching CA, Boehm M, Sala-Newby GB, George SJ (2006) Regulation of smooth muscle cell proliferation by beta-catenin/T-cell factor signaling involves modulation of cyclin D1 and p21 expression. Circ Res 99:1329-1337

Rahmani M, Read JT, Carthy JM, McDonald PC, Wong BW, Esfandiarei M, Si X, Luo Z, Luo H, Rennie PS, McManus BM (2005) Regulation of the versican promoter by the beta-cateninT-cell factor complex in vascular smooth muscle cells. J Biol Chem 280:13019-13028

Rommel C, Bodine SC, Clarke BA, Rossman R, Nunez L, Stitt TN, Yancopoulos GD, Glass DJ (2001) Mediation of IGF-1-induced skeletal myotube hypertrophy by $\mathrm{PI}(3) \mathrm{K} / \mathrm{Akt} / \mathrm{mTOR}$ and $\mathrm{PI}(3) \mathrm{K} /$ Akt/GSK3 pathways. Nat Cell Biol 3:1009-1013

Schaafsma D, McNeill KD, Stelmack GL, Gosens R, Baarsma HA, Dekkers BG, Frohwerk E, Penninks JM, Sharma P, Ens KM, Nelemans SA, Zaagsma J, Halayko AJ, Meurs H (2007) Insulin increases the expression of contractile phenotypic markers in airway smooth muscle. Am J Physiol Cell Physiol 293:C429C439

Slater SC, Koutsouki E, Jackson CL, Bush RC, Angelini GD, Newby AC, George SJ (2004) R-cadherin:beta-catenin complex and its association with vascular smooth muscle cell proliferation. Arterioscler Thromb Vasc Biol 24:1204-1210

Taurin S, Hogarth K, Sandbo N, Yau DM, Dulin NO (2007) Gbetagamma-mediated prostacyclin production and cAMP-de- pendent protein kinase activation by endothelin-1 promotes vascular smooth muscle cell hypertrophy through inhibition of glycogen synthase kinase-3. J Biol Chem 282:19518-19525

Tetsu O, McCormick F (1999) Beta-catenin regulates expression of cyclin D1 in colon carcinoma cells. Nature 398:422-426

Uglow EB, Slater S, Sala-Newby GB, guilera-Garcia CM, Angelini GD, Newby AC, George SJ (2003) Dismantling of cadherinmediated cell-cell contacts modulates smooth muscle cell proliferation. Circ Res 92:1314-1321

Wang X, Xiao Y, Mou Y, Zhao Y, Blankesteijn WM, Hall JL (2002) A role for the beta-catenin/T-cell factor signaling cascade in vascular remodeling. Circ Res 90:340-347

Wang Z, Wang DZ, Pipes GC, Olson EN (2003) Myocardin is a master regulator of smooth muscle gene expression. Proc Natl Acad Sci U S A 100:7129-7134

Woodruff PG, Dolganov GM, Ferrando RE, Donnelly S, Hays SR, Solberg OD, Carter R, Wong HH, Cadbury PS, Fahy JV (2004) Hyperplasia of smooth muscle in mild to moderate asthma without changes in cell size or gene expression. Am J Respir Crit Care Med 169:1001-1006

Wu B, Crampton SP, Hughes CC (2007) Wnt signaling induces matrix metalloproteinase expression and regulates $\mathrm{T}$ cell transmigration. Immunity 26:227-239

Zhang X, Gaspard JP, Chung DC (2001) Regulation of vascular endothelial growth factor by the Wnt and K-ras pathways in colonic neoplasia. Cancer Res 61:6050-6054 